\title{
A study of processes active in regeneration of different sweet cherry varieties
}

\author{
Vaszily, B. \\ Centre for Agricultural Sciences and Engineering, University of Debrecen 138 Böszörményi St., \\ 4032 Debrecen, Hungary
}

\begin{abstract}
Summary: Cherries belong to the group of fruit trees, which require little attention in pruning. The process of getting bald branches is less accentuated, which is associated with the light requirement of organs changing along with the aging process. The growing habits of the varieties (length and number of growing shoots, etc.) is closely related with the productivity of fruiting parts. The ability of regeneration and the functional effectiveness of fruiting structures are expressed by the distribution according to their age. The differences registered justify the necessity to develop pruning policies for each particular type of variety. For that purpose, we have to examine the age dependency of the processes related to regeneration, which may serve as starting point of a pruning strategy. Growth of some parts should be stimulated in order to develop or regenerate fruiting parts. Some branches need to be rejuvenated, partially, as an antidote to progressive senescence. Every intervention is aimed to strengthen the development of the most productive constructions. Reactions induced by rejuvenation should be expressed in fruiting intensity. A pruning program adapted to the particular variety as well as to the actual phase of a rotating pruning system should anticipate results.
\end{abstract}

Key words: regeneration, sweet cherry, pruning

\section{Introduction}

Competitiveness of fruit production on the worldwide scale is closely dependent on fruit quality. One of the most easily accepted fruit species is the sweet cherry, which's quality is expressed first of all by the size of the fruit. Fruits with a diameter larger than $25 \mathrm{~mm}$ are sold by a high price on the market. Fruit size is a property of the variety, but it is also dependent on growing conditions, especially technology. In the case of sweet cherry, breeding and growing techniques aimed to increase fruit size. The improvement of fruit size and yields together need, absolutely, the intensification of growing practices (Brunner, 1990; Apostol \& Brózik, 1998; Apostol, 2003; Hrotkó, 2004; Balázs, 2004; Simon, 2004).

Among the sweet cherry varieties grown, there are substantial differences regarding their growing properties, light requirements of the different fruiting structures, the loss of branches and getting bald as well as in ability of regeneration. Therefore, it is prime interest to be informed upon the special properties of the current varieties in order to find the optimum policies of technological interventions (Brunner, 1991; Gonda, 2003; Király \& Gonda, 2004, Gonda \& Király, 2005, Király et al., 2005; Gonda et al., 2007).

In the present study, we aimed to find the special measures for the most important cherry varieties in order to maintain their productivity of possibly highest quality. Which kind of fruiting structures are developed and maintained as productive, which are less exposed to senescence and most prone to be rejuvenated even by inducing growth from hidden buds.

\section{Material and methods}

Experiments have been performed in at Debrecen-Pallag, on the Experimental Farm of Horticulture and Regional Research Centre.

The cherry trees were planted in 2000, on Prunus mahaleb stock, at $4 \times 1 \mathrm{~m}$ planting design, trained to a slender (super) spindle crown. In the collection, there were nearly 60 cherry varieties, but for the study, 7 were selected as considered most important ('Linda', 'Axel', 'Stella', 'Germersdorfi 3', 'Isabella', 'Sunburst', 'Van').

In our present work, we concentrated on the lower third part of the crown, on branches with the purpose to test the less favourable part of the tree, by two reasons: there is less tendency to regeneration because of the polarity proper to the whole tree, on the other hand, if we find a measure to stimulate regeneration, the chance to test its beneficial effect will be higher with $30-50 \%$ than on the middle or upper parts of the crown.

We cut back the branches of $2-6$ year age. The length of the stump left was about 2-2.5 times longer than diameter of the stump. After sprouting of growth from hidden buds, the result has been rated as rosette or as shoot (short or long internodes). Summing up the results, the ability of regeneration has been determined. Shoots (with long internodes) have been specified according to the age and length of the stumps.

The productivity of the cherry varieties has been characterised by the number of fruiting structures existing on branches of different age. 


\section{Results}

On Figure 1, the ability of regeneration on parts of different age are characterised by indicating the number of growing points. It is of interest that only one variety, 'Linda' was able to produce regenerating growth on the 2year-old stumps.

On the 3-year-old stumps, also 'Linda', as well as 'Stella' and 'Van' produced growth with the most growing points, whereas 'Sunburst' did not produce any growth on 3year-old stumps. On 4-year-old stumps, 'Sunburst' and 'Germersdorfi 3' produced growth, whereas on 5-year-old stumps 'Van' and 'Axel' excelled. It is of interest that 'Isabella' and 'Sunburst' renewing growth was seen on 6-year-old stumps. Variety 'Isabella' was outstanding, as it produced nearly equal intensity of regeneration on stumps of different age, that means, it was the most vital variety.

Figure 2 shows the regenerating long shoots only. Those are more valuable because they may continue ramification and give chance to further regeneration. Variety 'Germersdorfi 3' is especially active on the 3-year-old parts, but it is also visible that only in this generation developed long shoots. 'Axel' and 'Stella' grew also many long shoots on 3year-old stumps. 'Isabella', as former indicated, was most vital on the 6-year-old stumps. 'Van' exhibited a good potential of regeneration on all parts of different age. 'Sunburst', on the other hand, produced rosettes only.

If we consider the intensity of growing fruiting bouquets on cherry varieties (Table 1) we may conclude as follows. On two-year-old parts, all varieties develop considerable number fruiting bouquets, which are considered as most valuable

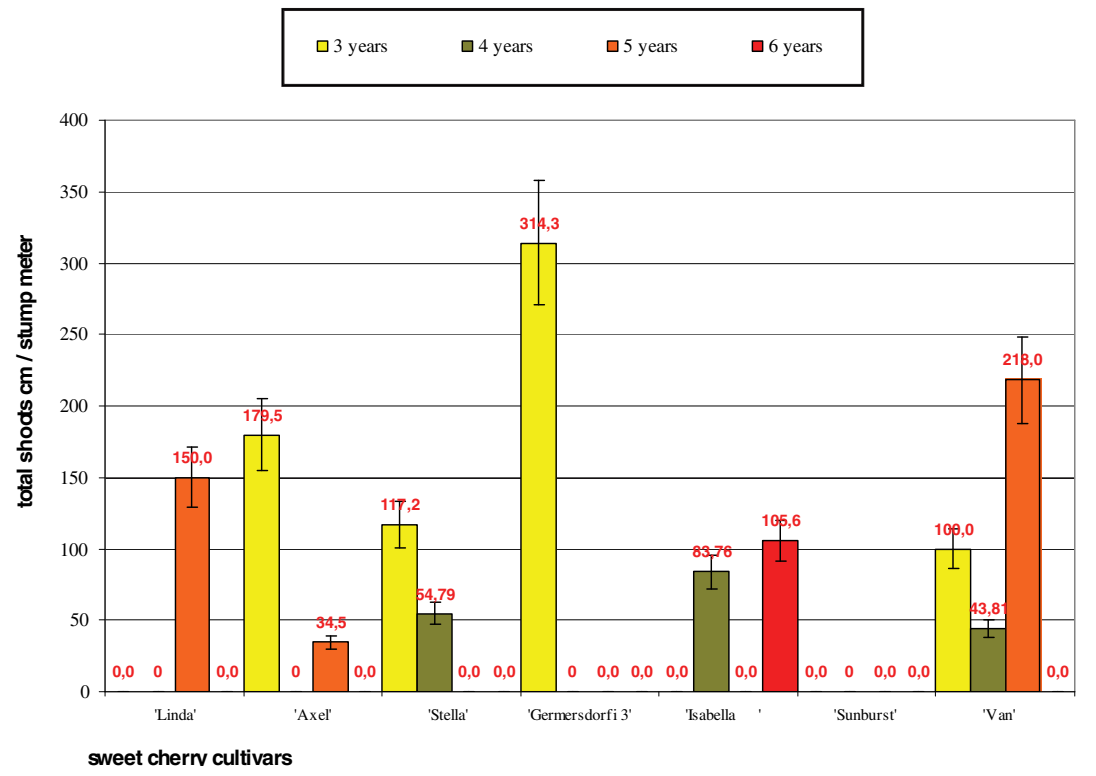

Figure 2: Abilities of regeneration on parts of different age considering all shoot lengths in cherry varieties (Debrecen-Pallag, 2009) fruiting structures. In 'Germersdorfi 3' and 'Stella', there is a considerable number of single buds too, being all growing points. On 3-year-old parts, the varieties 'Linda', 'Axel', 'Sunburst' and 'Van' produced equally as many bouquets as on the 2-year-old parts. 'Germersdorfi 3' produced half as many, whereas 'Stella' one third as on the 2-year-old parts. In variety 'Isabella', the number of bouquets diminished with the age of the branch. On the contrary, 'Germersdorfi 3' and 'Axel' were still very productive even on their 4-year-old fruiting parts.

\section{Conclusions}

The study allows the following conclusions. In the sweet cherry varieties examined, it could be suggested that a partial rejuvenations are worth while on the 3-5-year old parts. Among the varieties studied, the variety 'Isabella' should be preferably rejuvenated on the 4-6-year-old parts. On the variety 'Linda', older than 4-year-old parts ought to be changed by all means.

With growing age, differences between varieties are gradually increasing from the point of view of building up fruiting structures as well as of abilities of regeneration. Information referring to those abilities will be necessary for timing pruning interventions of rejuvenation and the optimum distribution of fruiting structures of different age.

It is evident that a variety-specific technology of pruning interventions is needed for each variety as a condition of obtaining regular yields of high quality fruit. 
Table 1: Fertility of fruiting parts of different age in cherry varieties (Debrecen-Pallag, 2009)

\begin{tabular}{|c|c|c|c|c|c|c|}
\hline & $\begin{array}{l}\text { Single buds } \\
\text { per meter }\end{array}$ & $\begin{array}{c}\text { Bouquets } \\
\text { per meter brach }\end{array}$ & $\begin{array}{c}\text { Single buds } \\
\text { per meter }\end{array}$ & $\begin{array}{c}\text { Bouquets } \\
\text { per meter brach }\end{array}$ & $\begin{array}{l}\text { Single buds } \\
\text { per meter }\end{array}$ & $\begin{array}{c}\text { Bouquets } \\
\text { per meter brach }\end{array}$ \\
\hline \multicolumn{7}{|c|}{ Age of the fruiting parts (years) } \\
\hline Sweet cherry varieties & \multicolumn{2}{|l|}{2} & \multicolumn{2}{|l|}{3} & \multicolumn{2}{|l|}{4} \\
\hline 'Germersdorfi3' & 3.86 & 18.71 & 2.2 & 9.1 & 1.37 & 17.81 \\
\hline 'Isabella' & 1.14 & 15.11 & 2.21 & 3.09 & 1.51 & 3.03 \\
\hline 'Linda' & 0.48 & 11.87 & 0 & 11.76 & 0 & 0 \\
\hline 'Axel' & 0 & 31.25 & 4.22 & 13.25 & 1.72 & 9.19 \\
\hline 'Van' & 1.58 & 12.63 & 0.33 & 13.05 & 2.13 & 1.06 \\
\hline 'Sunburst' & 2.62 & 12.42 & 0 & 11.66 & 0 & 2.27 \\
\hline 'Stella' & 3.82 & 23.47 & 3.96 & 8.49 & 0 & 2.44 \\
\hline
\end{tabular}

\section{References}

Apostol, J. (2003): Cseresznye- és meggynemesítés, a fontosabb fajták leírása. (In: Hrotkó K. (szerk.) (2003): Cseresznye és meggy.) Mezőgazda Kiadó, Budapest, 39.

Apostol, J. \& Brózik, S. (1998): Cseresznye. (In: Soltész M. (szerk.) (1998): Gyümölcsfajtaismeret és -használat.) Mezőgazda Kiadó, Budapest, 310.

Brunner, T. (1991): A cseresznye és a meggy metszése, koronaalakítása. Mezőgazdasági kiadó, Budapest.

Brunner, T. (1990): Kis fákon nagy termés. Mezőgazdasági Kiadó, Budapest

Gonda, I. (2003): Metszést kiegészítő eljárások. (In: Papp J. (szerk): Gyümölcstermesztési alapismeretek.) Mezőgazda Kiadó, Budapest, 300-305.
Gonda, I. \& Király, K. (2005): A nyári metszés hatása a meggyfajták növekedésére és gyümölcsminőségére. Kertgazdaság, 37 (1): 45-52.

Gonda, I., Király, K. \& Holb, I.J. (2007): Examination of growth of cherry cultivars adapted to intensive production. Acta Hort., 732: 429-434.

Hrotkó, K. (2004): Meggy- és cseresznyetermesztés intenzív ültetvényekben. In: Inántsy F.-Balázs K. (2004): Integrált növénytermesztés: Meggy, Cseresznye. Agroinform Kiadó, Budapest. 219-236.

Király, K. \& Gonda, I. (2004): A fajta szerepe és jelentősége a cseresznye intenzív termesztéstechnológiájában. Debreceni Egyetem Agrártudományi Közlemények, 13: 81-84.

Király, K., Gonda, I. \& Holb, I. (2005): Cseresznyefajták vegetatív és generatív tulajdonságainak összehasonlító vizsgálata. Kertgazdaság, 37 (1): 33-44.

Simon, G. (2004): Cseresznye. (In: Papp J. (szerk.), A gyümölcsök termesztése.) Mezőgazda Kiadó, Budapest, 264-295. 